Prace Literackie LVIII

Wrocław 2018

https://doi.org/10.19195/0079-4767.58.5

MAKIKO KIHARA

ORCID: 0000-0001-9440-6690

Uniwersytet Tokijski (The University of Tokyo)

\title{
Waśnie martyrologiczne Wielkiej Emigracji. Demokraci wobec Mickiewicza
}

W dzisiejszych czasach jedną z żywych tradycji polskiego romantyzmu pozostaje dyskurs martyrologiczny, obecny w kręgu konserwatywnie ukierunkowanej części polskiej inteligencji. Tę nową tendencję, będącą pochodną katastrofy smoleńskiej, trafnie opisał Tomasz Plata w swojej książce Pośmiertne życie romantyzmu w rozdziale zatytułowanym Marzenie o klęsce ${ }^{1}$. Zainteresowania badawcze skłaniają mnie do postawienia pytania, jak wyglądał ów dyskurs w fazie genetycznej, embrionalnej. Nie sposób wówczas przecenić wpływu Mickiewiczowskiej historiozofii, która skrystalizowała się pod koniec 1832 roku w jego działalności literackiej oraz politycznej. Istotnym zadaniem badawczym pozostaje zatem kwestia topiki martyrologicznej w literaturze emigracyjnej po powstaniu listopadowym oraz ustalenie zasięgu i rezonansu społecznego Mickiewiczowskiej martyrologii w emigracyjnej logosferze. W tym kontekście pisma polityczne demokratów ideowo oddalonych od Mickiewicza stanowią ważny układ odniesienia i przynoszą odmienny wariant wyobraźni polityczno-historycznej. Jednocześnie należy zwrócić uwagę, że istniał pewien wspólny język martyrologiczny wywodzący się ze wspólnoty losu, świeżych doświadczeń powstańczych.

W tym artykule przedstawię Mickiewiczowską działalność literacko-polityczną dotyczącą narodowej martyrologii, a następnie spróbuję wyznaczyć wspólny kod motywów martyrologicznych, na tle którego - w trzecim kroku — postaram się wydobyć cechy charakterystyczne martyrologicznego języka demokratów w latach trzydziestych XIX wieku. Wśród obozów politycznych Wielkiej Emigracji w nurt demokratyczny wpisują się Komitet Narodowy Polski,

\footnotetext{
* Artykuł powstał w ramach grantu JSPS KAKENHI, nr rejestracyjny projektu 16J04689.

${ }^{1}$ T. Plata, Pośmiertne życie romantyzmu, Warszawa 2017, s. 33-62.
} 
Towarzystwo Demokratyczne Polskie oraz Gromady Ludu Polskiego ${ }^{2}$. Można w dodatku przyjąć, że wśród najważniejszych środowisk emigracyjnych najsilniej swoją obecność zaznaczyło Towarzystwo Demokratyczne Polskie ze względu na spójność swej ideologii oraz dużą dyscyplinę organizacyjną. Z kolei jako jedno z pierwszych ugrupowań Wielkiej Emigracji bardziej umiarkowany Komitet Narodowy Polski, czyli Komitet Joachima Lelewela, dostarcza interesujących materiałów pozwalających lepiej zrozumieć, jaką formę przybrała retoryka martyrologiczna przed przyjazdem Mickiewicza do Paryża, w początkowym okresie konstytuowania się polskiej emigracji polistopadowej. Będę tu zatem przede wszystkim omawiać pisma KNP oraz TDP z pierwszego dziesięciolecia historii Wielkiej Emigracji.

Dziady drezdeńskie i Księgi narodu polskiego i pielgrzymstwa polskiego drukowano jesienią 1832 roku, a ich egzemplarze najpierw — w celu ominięcia cenzury i policyjnych barier - przesłano do kraju. Z tego powodu do francuskich środowisk emigracyjnych dotarły one dopiero pomiędzy grudniem 1832 a początkiem stycznia 1833 roku. Już przed rozpowszechnieniem Mickiewiczowskiej interpretacji cierpień Polski opartej na analogii do Męki Pańskiej można znaleźć motywy martyrologiczne w pismach zarówno literackich, jak i politycznych. Mówiąc o martyrologicznych motywach, mam na myśli różnorodne formy ekspresji słownych, w których autor nadaje cierpieniu Polski pozytywne znaczenia lub szczególną wartość jako ważnego składnika tożsamości kolektywnej. Wolno sądzić, że martyrologiczne ekspresje, nie tylko piśmiennicze, ale i ikonograficzne (w postaci rysunków, ilustracji, obrazów) były reakcją na traumę rozbiorów oraz świeżą klęskę powstania listopadowego. Jak wiadomo, narodowa martyrologia stanowiła również fundamentalny element ideowy polskiego mesjanizmu ${ }^{3}$.

Od jesieni 1832 do czerwca 1833 roku Mickiewicz prowadził intensywną działalność literacko-polityczną i publicystyczną (między innymi wydał Dziadów część III oraz Księgi narodu polskiego i pielgrzymstwa polskiego, pisał odezwy, redagował „Pielgrzyma Polskiego”). W ważnym momencie, gdy emigracja się organizowała, stworzył spójny system poglądów i postulatów, który w pełni zasługuje na miano projektu martyrologiczno-mesjanistycznego ${ }^{4}$. Był to program

${ }^{2}$ Gromady zostały zorganizowane w 1835 roku przez najbardziej radykalnych członków TDP, takich jak Tadeusz Krępowiecki czy Stanisław Worcell. Wskutek nieprzejednanego stanowiska w sprawie z innymi ośrodkami emigracyjnymi ich działalność nie odniosła konkretnych rezultatów i w 1840 roku większość członków odeszło. W latach czterdziestych pod wpływem Zenona B. Świętosławskiego Gromady wzmacniały charakter religijno-mistyczny. Zob. W. Jodko-Narkiewicz, Historia i system socjalizmu utopijnego wśród emigracji polskiej 1834-1846 r., [w:] W. Narkiewicz-Jodko, S. Dyksztajn, Polski socjalizm utopijny na emigracji, Kraków 1904.

${ }^{3}$ A. Wawrzynowicz, Spór o mesjanizm. Rozwój idei, Warszawa 2015, s. XI; P. Rojek, Mesjanizm integralny, „Pressje” 2012, nr 28, s. 40.

${ }^{4}$ Temat ten omówiłam w referacie Martyrologium Polonorum 1832 - Mickiewiczowski projekt literacko-polityczny na międzynarodowej konferencji naukowej „Pamięć i polityka w literaturze polskiej XIX i XX wieku”, Uniwersytet im. Adama Mickiewicza, Poznań 11-12.05.2018, [w druku]. 
literacko-ideowy, w którym - interpretując tragiczne doświadczenia Polski jako figurę Męki Pańskiej - poeta zachęcał do ich upamiętnienia i propagował ducha poświęcenia się; projekt ten miał charakter wybitnie tożsamościowy, mający na celu zintegrowanie i sprofilowanie właśnie tworzącej się wspólnoty emigracji. Wyraźnie świadczy o tym odezwa Mickiewicza zatytułowana Do Towarzystwa Literackiego Polskiego w Paryż $u^{5}$ z 11 października 1832 roku, w której poeta apeluje o utworzenie wielkiej, cyklicznej księgi męczenników polskich. Takie przedsięwzięcie, gdyby zostało podjęte i zrealizowane, wymagałoby gruntownej, wieloosobowej pracy, angażującej pamięć i świadomość narodową polskich uchodźców. W Dziadach drezdeńskich oraz Księgach narodu i pielgrzymstwa polskiego poeta czerpał z literackiej tradycji dramatu religijnego i stylu biblijnego. Co znamienne, w odezwie Do Towarzystwa Literackiego nawiązał bezpośrednio do zinstytucjonalizowanego systemu propagowania kultu męczenników w Kościele rzymskokatolickim, który od XVI wieku przybrał formę słynnej księgi Martyrologium Romanum, stanowiącej słownik biograficzny świętych i podstawę kalendarza liturgicznego ${ }^{6}$. Konsekwentne wcielanie w czyn projektu martyrologiczno-mesjanistycznego przez Mickiewicza widzimy w artykułach z „Pielgrzyma Polskiego”, którego redakcją poeta zajmował się od końca marca do końca czerwca 1833 roku. Znaczenie tego projektu w kontekście kształtowania dyskursu martyrologicznego jest nie do przecenienia - Mickiewicz dokonał rewaloryzacji i chrystianizacji cierpień narodowych, nadając im rangę systemu, programu narodowej pamięci.

W jaki sposób motywy martyrologiczne pojawiły się w pismach politycznych nurtu lewicowego w pierwszej fazie emigracji — przed przyjazdem Mickiewicza do Paryża? Sądzę, że wiedzy na ten temat dostarczają nam pisma Komitetu Narodowego Polskiego zorganizowanego pod prezesurą Joachima Lelewela 8 grudnia 1831 roku.

Akt zawiązania się Komitetu jest dokumentem poprzedzającym Organizację ogólnych zgromadzeń $i$ wyboru członków Komitetu Narodowego datowaną na 8 grudnia 1831 roku, która zawiera zasady działalności ugrupowania. Akt ten promuje braterstwo narodów francuskiego i polskiego, wskazując na dotychczasowe przypadki współpracy obu narodów i polsko-francuskiego braterstwa broni. Zwraca tu uwagę obrazowe użycie jako synekdochy leksemu „krwi”, wyrażającego ofiarę, męczeństwo. Służyło to podkreśleniu więzów łączących oba narody:

${ }^{5}$ A. Mickiewicz, Do Towarzystwa Literackiego Polskiego w Paryżu, [w:] idem, Dzieła. Wydanie Rocznicowe, t. 6. Pisma filomackie. Pisma polityczne z lat 1832-1834, oprac. M. Witkowski, C. Zgorzelski, przy współpracy A. Paluchowskiego, Warszawa 2000, s. 189.

${ }^{6}$ Martyrologium Rzymskie oraz elogia świętych i błogosławionych z niektórych martyrologiów zakonnych, przeł. i oprac. P. Turbak, Kraków 1967. Pierwsze thumaczenie martyrologium na język polski, dokonane przez jezuitę ks. Nikowskiego, pojawiło się w Krakowie w 1591 roku pod tytułem Martyrologium Kościoła rzymskiego. Później, w 1747 roku, wydano rozszerzoną wersję tego martyrologium w Sandomierzu, potem ponownie na nowo książka została wydana w 1799 roku. 
Krwią Francuzów i polską te same skropiły się pola; [...] ich krwią zmieszaną zrumieniły się wody Borystenu i Tagu. Przez lat dwadzieścia, bo od 1795 do 1815, dwakroć sto tysięcy Polaków legło pod sztandarami Francji, a krew ich zapłaciła za prawo obywatelstwa drugich ${ }^{7}$.

W tym „krwawym” obrazowaniu nie sposób przeoczyć pozytywnej wymowy interpretacji martyrologii. Krew jest świadectwem miłości do wolności, która jednoczy oba narody.

W dalszej części aktu założycielskiego Komitetu Lelewela napotykamy ciekawy wywód, w którym męczeństwo polskie prowadzi do zmartwychwstania ojczyzny. Ten fragment następuje po obrazie ujarzmionej przez ciemiężyciela Polski:

Polak, w tej chwili błąkający się, w tej chwili wygnaniec, swoje gościnne progi otworzyłby ludom uciśnionym.

Stało się! Dziś my żądamy przytułku; a chcąc choć w najdalszym zakątku świata żywić się wspomnieniem ojczyzny i wiarą w jej zmartwychwstanie, łączymy się na gościnnej Franków ziemi, sądząc, że do tego nabyliśmy prawa ${ }^{8}$.

Tutaj jeszcze nie widzimy silnej konotacji mesjanistycznej w słowie ,zmartwychwstanie". Nie ma konkretnego przyczynowo-skutkowego związku między cierpieniem a przyszłym odrodzeniem Polski. Można natomiast zauważyć, że żądając od innych narodów europejskich braterstwa i sojuszu ludów, leleweliści znaleźli swoisty argument „negocjacyjny” między innymi we własnym cierpieniu.

Retoryka martyrologiczna klarownie pojawia się po raz pierwszy w odezwie KNP Do tułaczów polskich, z powodu znaku wojskowego polskiego ,Virtuti Militari” wojsku rosyjskiemu rozdanego z 4 lutego 1832 roku. Leleweliści oznajmiają, że ów rozkaz Mikołaja, czyli przyznawanie orderu polskiego Virtuti Militari Rosjanom, którzy wzięli Warszawę, jest równoznaczny z niszczeniem narodowości honorowych znaków Polaków, pogwałceniem instytucjonalnej rangi tego odznaczenia. Dalej wyjaśniają cel cara: „Nie mogąc tułaczów polskich żelaznym ramieniem dosięgnać, chciał przynajmniej znak ich honorowy sponiewierać"9. Końcowy akapit tej odezwy jest moralną reakcją na to bluźniercze wydarzenie:

Was zaś, Rodacy, niechaj nie zasmuca ta grabież; wszak więcej straciliście: ojczyznę; wszak nie biliście się dla znaku, ale dla niej. - Tułacze, jesteście świętością pielgrzymów odziani. - Znakiem dla was jest smętność na twarzy rozlana, są łzy po stracie kraju płynące; honorem - nieszczęście [wyr. - M.K. $]^{10}$.

Co znamienne, sakralizowanie emigracji jako pielgrzymstwa obserwujemy już przed przyjazdem Mickiewicza (i oczywiście przed publikacją Ksiąg narodu i pielgrzymstwa polskiego). Widać tutaj, że polscy uchodźcy z bolesnych doświadczeń historycznych uczynili honorowy emblemat.

${ }^{7}$ Akt zawiąania się Komitetu, [w:] Zdanie sprawy z czynności Komitetu Narodowego Polskiego od grudnia 1831 do maja 1832, Paryż 1832, s. 24.

8 Ibidem, s. 25.

${ }^{9}$ Do tułaczów polskich, z powodu znaku wojskowego polskiego „Virtuti Militari” wojsku rosyjskiemu rozdanego, [w:] Zdanie sprawy..., s. 46.

${ }^{10}$ Ibidem, s. 48. 
Inne odezwy KNP świadczą także o tendencji do szczególnego traktowania cierpień narodowych. Czytamy: „Prowadziliśmy krwawą walkę z przemocą; dla wolności Polski, dla wolności Europy. Nasz upadek nadał ludom nowe życie, nowe dla nas obudza nadzieje" (12 marca 1832) ${ }^{11}$. Niekiedy autorzy podkreślają niewinność ofiary — piszą o nich „bezbronni bracia nasi”, „te niewinne sieroty"12. Amplifikacja cierpień narodowych oraz proces „uniewinniania”"13 narodu polskiego sygnalizują odwołanie się do historiozofii prowidencjalistycznej. Dowodem kilkakrotnie powtarzane słowo „los”14 oraz wyrażenie „te trudności były skutkiem gniewu bożego" 15 , a także ostatnie zdanie tej odezwy: „Komitet Narodowy Polski, tym zdarzeniem dotknięty, zapozywa przed sąd Boga, który raz przecie naznaczy godzinę wyroku, tych, co pozwolili na to morderstwo, i oddaje ich dziś złorzeczeniu i przekleństwu ludów"16.

Warto nadmienić, że obok motywów martyrologicznych miejscami daje o sobie znać autostereotyp przedmurza chrześcijaństwa. W Do tułaczów polskich na ziemie francuska przybylych (31 marca 1832) czytamy:

Byliśmy od wieków przedmurzem cywilizacji przeciw wschodniej i północnej dziczy. Dziś po zwaleniu tego przedmurza, nieprzyjaciel rodu ludzkiego po trupach poległych braci naszych w głąb Europy sięga i na zamordowanie jej wolności, nieciekłe jeszcze ze krwi, a męstwem naszym poszczerbione ostrzy miecze ${ }^{17}$.

Należy jednak zaznaczyć, że taki głos pobrzmiewający echem megalomanii narodowej nie przeważa w odezwach KNP, ponieważ członkowie Komitetu starali się wówczas o nawiązanie braterstwa $\mathrm{z}$ innymi ludami europejskimi, czego potwierdzeniem jest duża liczba odezw skierowanych do konkretnych narodów: Francuzów, Węgrów, Rosjan, do narodu włoskiego. W tych przypadkach polscy demokraci podkreślali raczej wspólną działalność, cechy łączące narody niż inność Polaków. Ważne, że w tekstach KNP z tego okresu można zaobserwować

${ }^{11}$ Adres trzystu kilkunastu ziomków z Besançon do komitetu narodowego w Paryżu, [w:] Zdanie sprawy..., s. 102. Por. „Ludy Europejskie, zagrożone o swe najdroższe swobody, wzywają nas do swego przymierza; bo od chwili, zwłaszcza naszego upadku, sprawa nasza ze sprawą ogólnej wolności nierozerwanym na wieczne czasy złączoną została ogniwem" (31 marca 1832) - Do tułaczów polskich na ziemię francuska przybytych, Komitet Narodowy w Paryżu, [w:] Zdanie sprawy..., s. 3-4.

${ }^{12} \mathrm{Z}$ powodu mordów na żotnierzu polskim $w$ Prusach popetnionych, komitet narodowy do ludów Europy, [w:] Zdanie sprawy..., s. 93.

13 Por. Z. Przychodniak, Podwójna obcość. Z dziejów polskiego stereotypu prześladowczego, [w:] idem, Poszukiwania, cierpienia i eksplozje. Dwanaście szkiców postromantycznych, Kraków 2016, s. 188.

14 „Kiedy nas los przeznaczył na tułaczów po obcych krajach, wzdychaliśmy, aby połączyć się z Wami” (20 sierpnia 1832) —Do komitetu polskiego w Paryżu, oddziat 440 Polaków przybytych na okręcie Saumon, [w:] Zdanie sprawy..., s. 174.

${ }^{15}$ Komitet narodowy polski, do ludów niemieckich, [w:] Zdanie sprawy..., s. 180.

${ }^{16}$ Z powodu mordów..., [w:] Zdanie sprawy..., s. 94.

${ }^{17}$ Do tułaczów polskich na ziemie francuska przybytych, [w:] Zdanie sprawy..., s. 3. 
wspólne dla całej emigracji przekonania, które tworzyły wówczas podatny grunt do rozwoju mesjanizmu ${ }^{18}$.

Wśród odezw Komitetu Lelewelowskiego szczególnie interesująca jest Odezwa do ludu izraelskiego, najprawdopodobniej ogłoszona 3 października 1832 roku $^{19}$. W dokumencie tym członkowie Komitetu, obficie posiłkując się cytatami ze Starego Testamentu, podkreślają analogie i zbieżności cierpień Polaków i ludu izraelskiego. Na początku wspominają o analogicznej sytuacji ludu izraelskiego, który marzy o powrocie na ziemię przodków, „do ziemi Abrahama i Dawida"20, porównują też Kazimierza Wielkiego z Salomonem, a trzech ciemiężycieli Polski z królami Asyrii, Egiptu i Babilonu. Następnie przypominają, że Rzeczpospolita Polska dała im schronienie i dobre warunki życia; z tego powodu proszą o pomoc i wspólne działanie z Polakami. Dalej wyjaśniają, że przez rozbiory Polska stała się ziemią niewoli również dla Żydów; wskazują na ucisk, upadek przemysłu i handlu wskutek rozbiorów. Podobnie jak w Akcie skierowanym do Francuzów autorzy odezwy akcentują walory dotychczasowej współpracy polsko-żydowskiej obrazem zmieszanej we wspólnych bojach krwi. W następnym zdaniu mowa o rzezi Pragi z 1794 roku:

zmieszała się krew synów Izraela, i niewiast ich, i dzieci niewinnych, i bezsilnych starców, ze krwią mężów, niewiast, starców i dzieci polskich $[\ldots]^{21}$.

Autorzy używają podobnej retoryki do tej z odezw skierowanych do Francuzów, aczkolwiek utożsamienie cierpień narodu polskiego z ofiarami ludu izraelskiego kieruje do uwznioślających kontekstów biblijnych, co sprawia, że paralela polsko-żydowska jeszcze bardziej służy afirmacji i sakralizacji męczeństwa polskiego. W kolejnym fragmencie pojawia się obraz ujarzmionej ziemi Polski czerpany wprost z Pierwszej Księgi Samuela:

Czyliż tedy nie ziściło się w tym wszystkim, na ujarzmionej przez króle ziemi polskiej, co wasz prorok Samuel o prawie królewskim zapowiedział (VIII, 11-16): „Pola, winnice i oliwnice, co najlepsze, weźmie; ze zboża i z dochodów winnic i z trzód, dziesięcinę brać będzie, aby rozdać między rzezańce sług i służebnice; sługi wasze i służebnice, i młodzieńce co lepsze, obróci na robotę swoję, córki wasze, w kucharki i piekarki, z was poczyni sobie oracze ról swoich i żeńce zboża i rzemieślniki zbrój i wozów swoich; syny wasze brać będzie i uczyni z nich jezdne: a wy będziecie mu nie-

${ }^{18}$ Andrzej Walicki pisze: „mesjanizm polski był reakcją na klęskę powstania listopadowego, entuzjazm, z jakim witano w Niemczech pokonanych, ale moralnie triumfujących powstańców, a następnie nadzieje i rozczarowania życia na emigracji. Wygnańcy polscy, upokorzeni klęską, ale nie godzący się z nią, pełni poczucia wielkości sprawy polskiej, żarliwie szukający i potrzebujący pociechy religijnej, a zarazem boleśnie rozczarowani do »urzędu kościoła«" — idem, Mesjanizm Adama Mickiewicza w perspektywie porównawczej, Warszawa 2006, s. 19.

19 Odezwa ta jest datowana „Paryż, 3 października 1830”. Natomiast ponieważ Lelewel przyjechał do stolicy Francji dopiero pod koniec października 1831 roku, KNP powstał zaś 8 grudnia tegoż roku, można przypuszczać, że chodzi tu o 3 października 1832 roku. Pamiętajmy, że kilka dni później, 11 października, jako jeden z pierwszych martyrologiczno-mesjanistycznych projektów Mickiewicz ogłosił odezwę Do Towarzystwa Literackiego, w której apeluje o tworzenie księgi męczenników polskich.

${ }^{20}$ Odezwa do ludu izraelskiego, [w:] Zdanie sprawy..., s. 243.

${ }^{21}$ Ibidem, s. 244. 
wolnikami”. Synowie Izraela! Nie tak to było, kiedy naród Polski był wolny i niepodległy, kiedy był Rzecząpospolitą, a tak się stało, kiedy został przez sąsiednich despotów, wraz z wami ujarzmiony ${ }^{22}$.

Skorzystanie z pytania retorycznego oraz cytatu z izraelskiego proroka i sędziego wzmacnia efekt wzbudzenia empatii i siłę perswazyjną apelu o wspólne działanie przeciw despotyzmowi. W następnym akapicie widać jeszcze wyraźniej uświęcenie cierpień oraz sprawy Polski:

Naród polski, nie mniej jak swoje, czuł i wasze krzywdy. I widzieliście go niedawno walczącego za wolność, usiłującego ziemie przodków swoich spod jarzma niewoli wyswobodzić. Wielu z was uczuło wspólną działania potrzebę; wielu czyniło piękne w gotowiźnie ofiary; inni podejmowali publiczną posługę; wielu wzięło się do broni, wspólnie z narodem Polskim walczyło, nie żałując swej krwi za świętą sprawę Polski²3.

Ponadto w odezwie tej można dostrzec elementy historiozofii prowidencjalistycznej:

Bóg wolą swoją i osłabił na ten koniec naród polski, i począł go trapić przeciwnościami. Nasłał nań nieprzyjaciół, którzy niszczyli zamożny kraj²4.

Zbliża się niewątpliwie czas wielkich zdarzeń. [...] Pobłogosławi Bóg narodom, wyzwoleniem i szczęściem ${ }^{25}$.

Wzmocnienie znaczeń cierpienia ( $w$ tym proces uniewinniania, a niekiedy „sakralizacji cierpień") oraz wiara prowidencjalistyczna i swoista megalomania narodowa, które rozproszone są w tekstach lelewelistów, możemy traktować jako odbicie wyostrzonej wrażliwości martyrologicznej. Frazeologia martyrologiczna wyłaniająca się z pism KNP byłaby wspólnym kodem większości środowisk emigracji w okresie popowstaniowym. Warto przypomnieć, że prowidencjalistyczną wiarę w sens cierpienia i przyszłe odrodzenie Polski można zaobserwować już w literaturze porozbiorowej — w takich utworach, jak Hymn do Boga (1805) Jana Pawła Woronicza czy głośna tragedia narodowa Barbara Radziwitłówna (1817) Alojzego Felińskiego ${ }^{26}$.

Jeszcze z innego powodu uznaję, że pisma KNP adekwatnie odzwierciedlają wspólny język emigracji z pierwszego okresu jej istnienia. Martyrologiczne motywy w sferze retorycznej, językowej służą celom perswazyjnym i terapeutycznym, o czym świadczy niekonsekwencja w stosowaniu tego rodzaju wyrażeń. Nie da się z nich wywnioskować spójnej struktury ideowej, konkretnego ,poglądu” na narodową martyrologię. Dyskurs martyrologiczny funkcjonuje tu przede wszystkim w celu dodawania otuchy, wzmocnienia aury emocjonalnej i poczucia jedności. To potwierdza, że wiele motywów martyrologicznych było dobrem wspólnym

22 Ibidem, s. 246.

23 Ibidem.

${ }^{24}$ Ibidem, s. 243.

25 Ibidem, s. 247, 248.

${ }^{26}$ Z. Przychodniak, Barbara Radziwittówna, czyli epifania przemienionego narodu, [w:] idem, Poszukiwania, cierpienia..., s. 178, 179. 
całej emigracji, a Mickiewicz temu wspólnemu kodowi nadał wyrazistość i sugestywność artystyczną.

Wśród pism lelewelistów dla języka demokratów charakterystyczne jest następujące wyrażenie, które pojawia się w Odezwie do Rosjan: „Zbliża się chwila do spełnienia wielkiego dzieła, do którego nadludzka siła ludy powołała"27. Prowidencjalistyczną frazeologią posłużono się tu dla wzmocnienia wiary w lud. Odezwa ta pokazuje jednocześnie pewną ciekawą relację między Mickiewiczem a demokratami. Jak wiadomo, Mickiewicz i Lelewel utrzymywali bliskie kontakty na scenie politycznej i w sferze prywatnej najwcześniejszego okresu emigracji. Gdy Mickiewicz przyjechał do Paryża w sierpniu 1832 roku, w biurze pocztowym czekał na niego prezes KNP. Warto także wspomnieć, że wcześniej w Dreźnie poeta zwierzył się ze swojej gotowości do działalności literacko-politycznej Lelewelowi ${ }^{28}$, który później popierał „Pielgrzyma Polskiego”. To właśnie poeta napisał dla KNP projekt omawianej Odezwy do Rosjan ${ }^{29}$. Gdy porównamy tekst oficjalnie wydanego dokumentu z Mickiewiczowskim projektem, z którego w końcu leleweliści skorzystali w małym stopniu, zauważymy interesujący fakt — w wersji Mickiewicza ani razu nie pojawia się słowo „lud”. Ta z pozoru drobna różnica stanie się wkrótce zasadniczym źródłem ideologicznego konfliktu poety z radykałami z Towarzystwa Demokratycznego Polskiego.

Jak wyglądał ten konflikt? Demokraci różnili się z poetą przede wszystkim antyszlachecką postawą i tym, że dążyli do odrodzenia Polski jako państwa o systemie demokratycznym, w którym lud powinien mieć „wszechwładztwo"30.

W Akcie założenia TDP z 17 marca 1832 roku, zwanym Małym Manifestem, można znaleźć poglądy na temat indywidualnych poświęceń całkowicie odmienne od późniejszej o pół roku odezwy Mickiewicza, w której apeluje on o utworzenie martyrologium narodowego. Polscy demokraci nazywali ducha poświęcenia się ,pamiątką przeszłości” i oceniali go pragmatycznie ${ }^{31}$ :

osobiste najnieograniczeńsze poświęcenie się nie przynosi pożądanego dla sprawy ogólnej pożytku, jeżeli nie jest kierowane prawdziwym pojęciem rzeczy, którego brak czyni wszelkie usiłowania bezskutecznymi, wszelkie czyny bezkorzystnymi ${ }^{32}$.

Główna różnica między nimi a Mickiewiczem dotyczyła jednak znaczenia rzymskiego katolicyzmu dla sprawy polskiej. Współzałożyciel TDP Adam Gu-

27 Odezwa do Rosjan, [w:] Zdanie sprawy..., s. 232.

28 „Czy będziesz mógł zająć się sam drukowaniem? Śmiem ci to proponować jedynie stąd, że to dziełko [Dziadów część III - M.K.] uważam jako kontynuację wojny, którą teraz, kiedy miecze schowane, dalej trzeba piórami prowadzić" - A. Mickiewicz, Dzieła. Wydanie Narodowe, t. 15. Listy. Część II, oprac. S. Pigoń, Warszawa 1954, s. 28-29.

29 A. Mickiewicz, [Projekt odezwy do Rosjan], [w:] idem, Dzieła. Wydanie Rocznicowe, t. 6, s. $305,306$.

${ }^{30}$ J.N. Janowski, Krótki katechizm polityczny, [w:] Towarzystwo Demokratyczne Polskie. Dokumenty i pisma, wyb. B. Baczko, Warszawa 1954, s. 44.

${ }^{31}$ Akt zatożenia, [w:] Towarzystwo Demokratyczne Polskie..., s. 5, 6.

32 Ibidem. 
rowski w sierpniu 1833 roku we francuskim czasopiśmie „L'Europe littéraire” napisał: „Mickiewicz jest człowiekiem przeszłości. Pogrążony stale w mistycznych rojeniach katolicyzmu"33. Przekonanie, że katolicyzm zagraża możliwościom odzyskania niepodległości, podzielał szeroki krąg emigrantów o poglądach demokratycznych, na przykład Seweryn Goszczyński ${ }^{34}$. Artykuł Jana Alcyaty O fanatyzmie religijnym ze względu na sity do powstania $w$ Polsce ${ }^{35}$ również stanowi interesujący materiał wyrażający spojrzenie polskich demokratów na ten temat. Autor na podstawie statystyki wyznań mieszkańców Polski wnioskuje, że fanatyzm religijny „sparaliżowałby jedność działania w całkowitej masie” 36 i osłabiłby potencjał powstańczy. Oczywiście Mickiewicz nie był fanatycznym katolikiem, ale przez demokratów, a nawet większość stronnictw emigracyjnych, które negatywnie oceniały Księgi, był postrzegany jako propagator ideologii „Polaka-katolika”. W owych czasach konflikt między poetą a demokratami był tak rozumiany; a przynajmniej polscy demokraci postrzegali różnicę postawy swojej i Mickiewicza właśnie z tej perspektywy ${ }^{37}$.

Chciałabym zarazem podkreślić, że nie oznacza to, iż religijna frazeologia była zupełnie obca i nieobecna w tekstach demokratów. Z dzisiejszej perspektywy uwagę przykuwa mocno religijny ton języka Mickiewicza, lecz nie są go pozbawione także publikacje stronnictw demokratycznych z XIX wieku. W Krótkim katechizmie politycznym (1834) pióra Jana Nepomucena Janowskiego, który według Bronisława Baczki jest ,niezmiernie charakterystycznym dokumentem dla podstaw światopoglądowych i poglądów społeczno-politycznych Towarzystwa"38, pojawia się przesłanie millenarystyczne: „Przyjście spodziewanego od dawna Mesjasza, zbawcy ludzkości, to jest powszechna rewolucja"39.

Znany jest również konflikt Mickiewicza z Tadeuszem Krępowieckim, który $\mathrm{w}$ paryskim przemówieniu $\mathrm{w}$ drugą rocznicę wybuchu powstania listopadowego gwałtownie potępiał szlachtę, widząc w niej przyczynę upadku Polski. Jako odpo-

${ }^{33}$ Cyt. za: Z. Stefanowska, Wstęp, [w:] A. Mickiewicz, Księgi narodu polskiego i pielgrzymstwa polskiego, oprac. Z. Stefanowska, Wrocław 1956, s. LXIII. Tekst oryginalny: „Mickiewicz est l'homme du passé. Toujours plongé dans les mystiques rêveries du catholicisme" - A. Gurowski, État actuel de la littérature en Pologne, „L'Europe littéraire. Journal de la littérature nationale et étrangère” 1833, nr 68, s. 273.

34 Por. S. Goszczyński, Moralna podstawa sprawy polskiej. Katolicyzm, czyli papizm, [w:] Towarzystwo Demokratyczne Polskie..., s. 227-240. Artykuł zamieszczono w Piśmie Towarzystwa Demokratycznego Polskiego, cz. 2, Poitiers 1840, s. 408-428.

35 J. Alcyato, O fanatyzmie religijnym ze względu na sity do powstania w Polsce, [w:] Pismo Towarzystwa..., cz. 2, s. 277-297.

36 Ibidem, s. 292.

37 Por. A. Walicki, Filozofia polskiego romantyzmu, Kraków 2009, s. 28-34.

38 J.N. Janowski, op. cit., s. 40.

${ }^{39}$ Ibidem, s. 49. Andrzej Walicki spostrzega socjalistyczny millenaryzm — „Chrystus-rewolucjonista” w pismach Gromad Ludu Polskiego oraz Ludwika Królikowskiego — idem, Filozofia..., s. 39-44. 
wiedź na to przemówienie Mickiewicz napisał satyryczny wiersz Do Franciszka Grzymaty (ostatecznie go nie opublikował) ${ }^{40}$ :

Słyszysz, że działo z Litwy przywiózł Krępowiecki

I rdzennym strzałem mierzy w cały stan szlachecki ${ }^{41}$.

$\mathrm{W}$ takim razie czym różniło się pojęcie ludu u demokratów i Mickiewicza? Współzałożyciel TDP Jan Nepomucen Janowski określił pojęcie ludu we wspomnianym Krótkim katechizmie politycznym (1834) następująco: „to jest niezmierna większość mieszkańców uciśniona przez mniejszość"42. Janowski pisze też, że człowiek to „istota przeznaczona do społeczeństwa i do wolności”"43 i że ponieważ „celem społeczeństwa jest utrzymanie przyrodzonych praw człowieka [...], ktokolwiek gwałci te prawa”, przestaje być „,członkiem społeczeństwa, czyli narodu"44. Demokraci widzieli pogwałcenie tych praw w samym systemie szlacheckich przywilejów. W ich rozumieniu lud był klasą społeczną, która stanowi podstawę narodu. W przypisie do swego „katechizmu” Janowski krytykował Lelewela i Mickiewicza za to, że odmawiają polskości „większości plebejuszów, mianowicie chłopów"45. Moim zdaniem krytyka Mickiewicza ze strony Janowskiego nie była w pełni trafna, jednakże pewne jest, że Mickiewicz rozumiał lud inaczej — przede wszystkim biblijnie, jako całość wspólnoty, a także, jeśli można tak powiedzieć, aklasowo i idyllicznie. Mickiewiczowski lud, Mickiewiczowskie idee dotyczące polskiego ludu to według Andrzeja Waśki „liryczny demokratyzm". Badacz stwierdza:

Mickiewicz ma odmienną koncepcję ludu niż teoretycy obozu demokratycznego. Jego „lud” jest, z jednej strony, nosicielem najwyższych wartości etycznych, przechowuje ustne podania przodków, w których wyraża się duch narodowy (,prawdy żywe”). Lud, do którego zalicza się także drobna szlachta, kieruje się prawami nie-pisanymi, a zinternalizowanymi w postaci przekazywanych z pokolenia na pokolenie norm i wzorów. Lud jest zdolny do prawdziwych i szczerych uczuć, z których płyną czyny obywatelskiego poświęcenia ${ }^{46}$.

Ta różnica poglądów na lud polski generuje ciekawy wariant funkcjonalizowania motywów martyrologicznych w pismach TDP. W okresie obowiązywania Małego Manifestu charakterystyczne dla TDP motywy martyrologiczne nie występują niemal wcale. Liczba tego rodzaju motywów jest mniejsza nawet niż

40 Jeden z satyryzujących demokratów tak zwanych Wierszy Franciszka Grzymaty, które powstały między listopadem 1832 a kwietniem 1833 roku. Uwagę przykuwa także antyżydowski ton, który był aluzją do Jana Czyńskiego, który miał żydowskie pochodzenie i wówczas był działaczem TDP.

${ }^{41}$ A. Mickiewicz, Do Franciszka Grzymały, [w:] idem, Dzieła. Wydanie Narodowe, t. 1. Wiersze, oprac. W. Borowy, L. Płoszewski, Kraków 1949, s. 365.

42 J.N. Janowski, op. cit., s. 40.

43 Ibidem, s. 41.

44 Ibidem, s. 46.

45 Ibidem, s. 51.

${ }^{46}$ A. Waśko, Romantyzm polityczny Adama Mickiewicza w latach 1832-1833, [w:] Temat polemiki: Polska. Najważniejsze polskie spory ideowo-polityczne, red. J. Kloczkowski, Kraków 2012, s. 121. 
w wypadku dokumentów KNP. Jednym z niewielu wyjątków będą pisma Janowskiego, działacza o umiarkowanych poglądach w porównaniu z jego kolegami ${ }^{47}$, który pisał w organie Towarzystwa następująco: „w niedoli i nadzieja jest połową szczęścia”48 albo cytując staropolskie przysłowie: „nie ma tego złego, co by na dobre nie wyszło - niewidziana ręka czasu może srodze ukarać królów za ich faryzeuszowskie działania względem ludów"49. Słowa te słabo nacechowane treściami martyrologicznymi są przede wszystkim formą pocieszenia. Bardziej jednoznacznie określone motywy martyrologiczne pojawią się dopiero później.

Nie było rychłej przemiany sytuacji politycznej w Europie, w którą w pierwszych latach każdy polski emigrant wierzy ${ }^{50}$. Mickiewicz już w drugiej połowie 1833 roku wycofał się z najbardziej radykalnych haseł martyrologicznych głoszonych na scenie politycznej, co więcej, zaniechał gorączkowej aktywności i zrezygnował z redagowania „Pielgrzyma Polskiego” ${ }^{51}$. W zmienionych okolicznościach — „po upłynieniu znacznego przeciągu czasu”52 — 4 grudnia 1836 roku demokraci wydali w Poitiers drugi dokument programowy, zwany Wielkim Manifestem. Sławomir Kalembka następująco podsumowuje ich poglądy z tego czasu:

Według tego aktu główna przyczyna upadku państwa polskiego była wewnętrzna, a nie zewnętrzna. Ale Polska jest Europie potrzebna, ma do spełnienia ważną misję — upowszechnienie zasad wolności i równości na wschodzie kontynentu rządzonym dotąd przez ciemnych despotów. Owa główna przyczyna osłabienia i upadku Polski to ograniczenie pierwotnego u wszystkich Słowian gminowładztwa, tzn. rządów ludu o formach republikańskich, do rządów tylko małej części narodu — szlachty. Z tego wynikła sprzeczność między interesami ludu a interesami szlachty, a w rezultacie słabość narodu jako całości ${ }^{53}$.

Ponieważ TDP oddziela tutaj Polskę ludu od Polski szlacheckiej, w martyrologicznych motywach podmiotem cierpiącym staje się lud polski. Rezultatem tego są liczne obrazy ludu cierpiącego z rąk uprzywilejowanych, czyli polskiej szlachty; oczywiście Mickiewicz nie opisywał tak polskich cierpień narodowych.

${ }^{47}$ S. Kalembka, Wielka Emigracja. Polskie wychodźstwo polityczne w latach 1831-1862, Warszawa 1971, s. 115, 116.

48 J.N. Janowski, Spomnienia przeszłości. Widoki na przyszłość, [w:] Towarzystwo Demokratyczne Polskie..., z. 1, s. 10.

49 Ibidem, s. 13.

${ }^{50}$ Kalembka pisze: „wiara w bliskość »wojny powszechnej za wolność ludów«, czyli demokratycznej rewolucji europejskiej, która wyzwoli również Polskę, była wówczas, w początkach emigracji, wśród większości wychodźców powszechna. Była prawdziwą wiarą” — idem, op. cit., s. 145.

51 Zob. S. Pigoń, Metamorfozy „Historii przyszłości” oraz Program polityczny „Pielgrzyma Polskiego", [w:] idem, Zawsze o nim. Studia i odczyty o Mickiewiczu, Warszawa 1998; Z. Trojanowiczowa, Mickiewicz , szalony” $i$,,rozsadny”. O pismach politycznych poety z lat 1832-1833, [w:] eadem, Romantyzm od poetyki do polityki. Interpretacje i materiaty, red. A. Artwińska, J. Borowczyk, P. Śniedziewski, Kraków 2010.

52 Uwagi centralizacji przy dyskusji nad Manifestem Towarzystwa Demokratycznego Polskiego, [w:] Towarzystwo Demokratyczne Polskie..., s. 111. Opublikowane w postaci okólnika Towarzystwa 30 sierpnia 1836 roku.

53 S. Kalembka, op. cit., s. 210. 
Autorzy Wielkiego Manifestu wskazują na cywilizujące Europę posłannictwo Polski, lecz przede wszystkim mnożą obrazy ludu polskiego cierpiącego niewolę w systemie feudalnym:

Lud polski z praw wszelkich wyzuty, ciemnotą, nędzą i niewolą przycieniony, wydartą mu przed wiekami ziemię, dotąd w krwawym pocie na cudzą korzyść uprawia $[\ldots]^{54}$.

Dalej autorzy stwierdzają, że naturalnie, uciśniony lud nie w pełni poświęcał się dla szlacheckiej Polski. Dopiero gdy zapanuje sprawiedliwość społeczna, w ludzie polskim rozwinie się uczucie prawdziwego poświęcenia się. Następnie czytamy:

Taki tylko wymiar sumiennej, szczerej, niedwuznacznej sprawiedliwości rozwinąc może w całej uciśnionych masie uczucie prawdziwego poświęcenia się [...]. Mało który naród zrównał narodowi polskiemu w miłości ojczystej ziemi; w poświęceniach żaden go nie przewyższył ${ }^{55}$.

Co znamienne, w celu uzasadnienia posłannictwa Polski wymienia się tutaj jako cechy wyjątkowe polskiego narodu nie tylko miłość do ojczyzny, lecz także uczucie poświęcenia się ${ }^{56}$. W dokumencie tym pojawia się jeszcze jeden motyw: „Tak nam jednak drogą jest Ojczyzna, tak mocno bolą nas jej rany, iż z żadnego wypadku, z żadnej przyjaznej okoliczności korzystać nie zaniedbamy"57. Widać, że demokraci kładą szczególny nacisk na męczeństwo nie narodu jako całości przenikniętej duchem wspólnej wiary chrześcijańskiej (jak u Mickiewicza), lecz zniewolonego ekonomicznie, społecznie i moralnie ludu polskiego.

Mocno martyrologiczną retoryką rozbrzmiewa także tekst z Okólników TDP z 4 listopada 1839 roku, zatytułowany Centralizacja Towarzystwa Demokratycznego Polskiego do ogółu Towarzystwa. W tym kilkudziesięciostronicowym tekście każda sekcja wygłasza opinię na temat kwestii: „Jakie położone być powinny zasady do utworzenia i organizacji siły zbrojnej w powstaniu, uważając ją pod względem politycznym?". Sekcja Poitiers, której tekst został zamieszczony na pierwszym miejscu, eksplikuje, że najlepszą bronią narodowego powstania jest siła polskiego ludu. Odbija się w tej analizie logika Wielkiego Manifestu — i tutaj Polskę dzieli się na dwa obozy: „Polskę szlachecką” i „Polskę ludu [ludową]”, a także potwierdza, że „Polska szlachecka” nie odrodzi się i tylko „Polska ludu” zdoła doprowadzić Polskę do stanu niepodległego. Sekcja Poitiers argumentuje dalej, że „Lud-męczennik” musi zostać „Ludem-wojownikiem”58, żeby wszędzie przynieść wolność z następujących powodów:

${ }^{54}$ Manifest Towarzystwa Demokratycznego Polskiego, [w:] Towarzystwo Demokratyczne Polskie..., s. 94.

55 Ibidem.

56 Oprócz tego wymienia także następujący powód: „Cierpiąca u nas ludzkość nie jest do cierpiącej ludzkości zachodniej Europy podobną; nie zaraziły jej zepsucie i egoizm klas uprzywilejowanych" — ibidem, s. 95.

57 Ibidem.

58 „Lud-męczennik, aby zgruchotał bezpowrotnie narzędzia swojego ucisku, aby się uwieńczył niemylnie tryumfem nad sprawcami swej niedoli, aby zasłynął w dziejach świata nieznaną chwałą, musi w całej swej masie Ludem-wojownikiem zostać" - Centralizacja Towarzystwa Demokratycz- 
Bo i komużby lepiej przystało mieć czułość na dolegliwości i być skorym do zaniesienia ulgi, do dania pomocy drugim, jeżeli nie temu, co sam największą miarę katuszy i boleści wycierpiał? Któżby znowu większym miał kogoś natchnąć zaufaniem, mocniejszą obudzić wiarę i w prawość chęci i w czystość zamiarów swoich, jeśli nie ten, co sam o najgwałtowniejsze krzywdy długie zapasy i nieprzerwany bój z niesprawiedliwością toczył? ${ }^{59}$

Korzystając z pytania retorycznego i paralelizmu, autorzy nadają wartość męczeństwu polskiemu i wzbudzają uczucie wyjątkowości polskiego narodu. Co ciekawe, martyrologiczny motyw odgrywa tu istotną rolę nie tylko w sferze wyrażenia, ale i wyraźnie funkcjonuje jako ważny składnik autorskiej argumentacji ideologicznej. Dalszym zdaniem autorzy zwięźle to podsumowują:

Tak więc obecne nieszczęście i cierpienia ludu polskiego torują mu drogę do rozległej i szczytnej misji w przyszłości, podnoszą i umacniają moralną jego potęgę, przed którą nie ostoi się zbrodnia najemną i niewolniczą ręką zasłaniana ${ }^{60}$.

Tego schematu myślowego, że cierpienie Polski staje się przyczyną wybraństwa polskiego narodu, nie można było dostrzec tak wyraźnie przed działalnością Mickiewicza w latach 1832 i 1833 . Widziałabym tu pewne echo Mickiewiczowskiego pasjonizmu i misjonizmu. Poza tym uderza to, że autostereotyp „Polaka-męczennika" współdzielili Mickiewicz i demokraci, tym bardziej że wielu spośród nich widziało zagrożenie w ideologii „Polaka-katolika”. To potwierdzałoby swoisty rezonans martyrologicznego projektu Mickiewicza, siłę oddziaływania autora Dziadów i Ksiąg narodu polskiego. Jednocześnie należy zwrócić uwagę na to, że wskazane motywy martyrologiczne w tekstach TDP odróżniają się od Mickiewiczowskich swoistym świeckim tonem oraz odmienną definicją podmiotu cierpiącego, czyli „ludu”. U Mickiewicza przecież ogół narodu polskiego (żołnierze, litewska młodzież, szlachta itp.) był podmiotem cierpiącym. Możemy więc stwierdzić, że demokraci dokonali znaczącej modyfikacji Mickiewiczowskiego schematu martyrologicznego.

Towarzystwo Demokratyczne Polskie było niewątpliwie promotorem, propagatorem nowocześnie pojmowanej idei demokracji i liberalnych koncepcji ustrojowych - i to nie tylko w skali polskiej. Wszak w swojej nazwie po raz pierwszy wśród europejskich organizacji politycznych użyło przymiotnika „demokratyczne”61. Pisma polskich emigrantów, działaczy i publicystów z kręgu TDP potwierdzają dobitnie, że topika martyrologiczna była ważnym elementem przeformułowywania narodowej narracji tożsamościowej po klęsce 1831 roku. Poszukiwania demokratów pokazują zarówno wspólne, jak i odmienne cechy budowania tej narracji w stosunku do Mickiewiczowskiego projektu. Z tego jednoznacznie wynika, że pierwotnie martyrologiczny język nie był zawłaszczony

nego Polskiego do ogółu Towarzystwa. Rozbiór kwestii. Sekcja Poitiers, [w:] Okólniki Towarzystwa Demokratycznego Polskiego od 25 grudnia 1838 do 20 lutego 1840, Poitiers 1840, s. 210.

${ }^{59}$ Ibidem, s. 210-211.

${ }^{60}$ Ibidem, s. 211.

${ }^{61}$ S. Kalembka, op. cit., s. 114. 
przez jedną stronę sceny politycznej, ale był o wiele bardziej neutralnie nacechowany, niż współcześnie sądzimy.

\section{Bibliografia}

Kalembka S., Wielka Emigracja. Polskie wychodźstwo polityczne w latach 1831-1862, Warszawa 1971.

Kihara M., Martyrologium Polonorum 1832 - Mickiewiczowski projekt literacko-polityczny, referat wygłoszony na międzynarodowej konferencji naukowej „Pamięć i polityka w literaturze polskiej XIX i XX wieku”, Uniwersytet im. Adama Mickiewicza, Poznań 11-12.05.2018, [w druku].

Martyrologium Rzymskie oraz elogia świętych i błogosławionych z niektórych martyrologiów zakonnych, przeł. i oprac. P. Turbak, WAM, Kraków 1967.

Mickiewicz A., Dzieła. Wydanie Narodowe, t. 1. Wiersze, oprac. W. Borowy, L. Płoszewski, Kraków 1949.

Mickiewicz A., Dzieła. Wydanie Narodowe, t. 15. Listy. Część II, oprac. S. Pigoń, Warszawa 1954.

Mickiewicz A., Dzieła. Wydanie Rocznicowe, t. 6. Pisma filomackie. Pisma polityczne z lat 1832 1834, oprac. M. Witkowski, C. Zgorzelski, współp. A. Paluchowski, Warszawa 2000.

Mickiewicz A., Księgi narodu polskiego i pielgrzymstwa polskiego, oprac. Z. Stefanowska, Wroclaw 1956.

Narkiewicz-Jodko W., Dyksztajn S., Polski socjalizm utopijny na emigracji, Kraków 1904.

Okólniki Towarzystwa Demokratycznego Polskiego od 25 grudnia 1838 do 20 lutego 1840, Poitiers 1840.

Pigoń S., Zawsze o nim. Studia i odczyty o Mickiewiczu, Warszawa 1998.

Pismo Towarzystwa Demokratycznego Polskiego, cz. 2, Drukarnia F.A. Saurin, Poitiers 1840.

Plata T., Pośmiertne życie romantyzmu, Warszawa 2017.

Przychodniak Z., Poszukiwania, cierpienia i eksplozje. Dwanaście szkiców postromantycznych, Kraków 2016.

Rojek P., Mesjanizm integralny, „Pressje” 2012, nr 28, s. 20-49.

Temat polemiki: Polska. Najważniejsze polskie spory ideowo-polityczne, red. J. Kloczkowski, Kraków 2012.

Trojanowiczowa Z., Romantyzm od poetyki do polityki. Interpretacje i materiały, red. A. Artwińska, J. Borowczyk, P. Śniedziewski, Kraków 2010.

Towarzystwo Demokratyczne Polskie. Dokumenty i pisma, wyb. B. Baczko, Warszawa 1954.

Walicki A., Filozofia polskiego romantyzmu, Kraków 2009.

Walicki A., Mesjanizm Adama Mickiewicza w perspektywie porównawczej, Warszawa 2006.

Wawrzynowicz A., Spór o mesjanizm. Rozwój idei, Warszawa 2015.

Zdanie sprawy z czynności Komitetu Narodowego Polskiego od grudnia 1831 do maja 1832, Drukarnia A. Pinard, Paryż 1832. 


\title{
Martyrological feuds of the Great Emigration. Democrats and Mickiewicz
}

\begin{abstract}
Summary
Today, the martyrological discourse is one of the most conspicuous traditions of Polish Romanticism. When searching for the genesis of this discourse, one cannot overestimate the importance of the literary and political activities of Adam Mickiewicz from the autumn of 1832 to the middle of 1833 . However, little is known about the problem of the resonance of Mickiewicz's martyrological language and about how this discourse functioned in various texts of the Great Emigration. This paper attempts to answer those questions in reference to left-leaning texts of Komitet Narodowy Polski (KNP) and Towarzystwo Demokratyczne Polskie (TDP) from the 1830s. A study of the writings of KNP has led the author to the conclusion that they represent a common martyrological code of the emigration's logosphere, while the TDP publications constitute an interesting variation of the martyrological collective imagination. The original character of the martyrological expression of the democrats stems from their views on the role of the people in regaining independence. On the other hand, certain common traits existed between TDP and Mickiewicz, which demonstrates that democrats modified the martyrological framework as a national narrative established by Mickiewicz.
\end{abstract}

Keywords: Polish Romanticism, Great Emigration, discourse, Adam Mickiewicz, Polish messianism 